\title{
Influence of Organic Manures on Yield Components of Triticum aestivum L
}

\author{
Ch. Sivanagalakshmi ${ }^{1 *}$, Narendra Singh ${ }^{2}$, Gajendra Singh $^{1}$, \\ Ankush Singh ${ }^{1}$ and Pragya Rawat ${ }^{3}$ \\ ${ }^{1}$ Department of Agronomy, ${ }^{2}$ Department of veterinary sciences, ${ }^{3}$ Department of Biotechnology \\ Alpine Institute of Technology, Premnagar, Dehradun (U.K), India \\ *Corresponding author
}

\section{A B S T R A C T}

\begin{tabular}{|l|}
\hline Ke y w o r d s \\
Organic manures, \\
$\begin{array}{l}\text { Vermicompost and } \\
\text { Farmyard manure, } \\
\text { Poultry manure }\end{array}$ \\
\hline Article Info \\
\hline $\begin{array}{l}\text { Accepted: } \\
\text { 24 July 2020 } \\
\text { Available Online: } \\
\text { 10 August 2020 }\end{array}$ \\
\hline
\end{tabular}

\begin{abstract}
Organic manures in agriculture add much needed organic and mineral matter to the soil. The organic matter added is an indispensable component of soil, and plays an important role in maintenance and improvement of soil fertility and productivity. The proper management of these makes it possible to increase the efficiency of use of soil and added nutrients. The Present experiment consisted of nine treatments $T_{1}: R D F, T_{2}: E C(1 / 4)$ basal + PM (3/4) basal, T $:$ FYM (1/4) basal + VC (3/4) basal, $\mathrm{T}_{4}:$ FYM (1/4) basal + PM (3/4) basal, $\mathrm{T}_{5}$ : EC (1/4) basal + VC (3/4) basal, $\mathrm{T}_{6}$ : FYM (1/4) basal + PM (3/4) top dressing 30DAS, $\mathrm{T}_{7}$ : EC (1/4) basal + VC (3/4) top dressing @ 30 DAS, T 8 : EC (1/4) basal + PM (3/4) top dressing at 30DAS, $\mathrm{T}_{9}$ : Control. The study revealed that, among the treatments, Ear length $(9.00 \mathrm{~cm})$, number of grains per ear $(40.78)$, grain weight per ear $(1.46 \mathrm{~g})$, grain yield per hectare $(28.53 \mathrm{q} / \mathrm{ha})$, straw yield per hectare $(46.26 \mathrm{q} / \mathrm{ha})$, harvest index $(38.83 \%)$, 1000 grain weight $(35.26 \mathrm{~g})$ Thus in the present study, it can be concluded that the $\mathrm{T}_{8}$ is the better treatment for wheat variety on basis of growth, yield and grain quality.
\end{abstract}

\section{Introduction}

Soil harbours dynamic microbial population, arthropods and others. This living phase is greatly stimulated by organic manure addition which acts as carbon and energy source for proliferating micro-organisms and they may intern alter the accompanying enzyme status accordingly, Sharma (2009). Integrated nitrogen management in fodder oats (Avena sativa) in hot arid ecosystem of Rajasthan. Interest in soil enzyme activity has increased recently since their activities are believed to reflect the potential capacity of soil to perform nutrient transformations. Since, soil microbial and enzyme systems are associated with organic manure management, incorporation of organic manures into soil not only plays an important role in soil chemical and biological activity, but also affects the rate at which nutrients become available to crop plants as well as other forms of life.

Good quality farmyard manure (FYM) is perhaps the most valuable organic manure. These results are in akin with Ghosh et al., (2001) in rice, Patil and Bhilare (2000) and Billore et al., (2009) in wheat (Patil and 
Bhilare, 2000). Better translocation of food reserves from source of sink leading to better filling of the seed, thus resulting in higher 1000 seed weight. It must be stressed that the value of FYM in soil improvement is due to its micronutrient content, besides helping in the improvement of soil structure and water holding capacity of soil (Naik and Gupta, 2010). Effect of plant density and integrated nutrient management on growth, yield, quality and economics of kale (Brassica oleracea var. acephala) in temperate region.

It stimulates the activity of microorganisms that make the plants to get the macro and micronutrients throughout the biological decomposition. nitrogen availability throughout the crop growth which caused by higher yield and results in conformity with Sharma and Vayas (2001) in wheat. Yield is the ultimate product of growth and yield parameters. Beneficial effects of earthworms and their cast were known as early as in Darwins era. But, the potential of the vermicompost to supply nutrient and support beneficial microbes is being recognized recently.

Vermicompost has the entire characteristic to use it as most valuable organic manure (Kale and Bano, 1986).Compost is the traditional source of nutrient for crops. It supplies large number of essential micronutrients, in addition to NPK, which are becoming deficient in the intensively cultivated areas.

Poultry manure is a good source of nutrients for crops. In this manure, 60 per cent of the nitrogen is present as uric acid, 30 per cent as more stable form of organic nitrogen and the balance as mineral nitrogen (Srivastava, 1998). The uric acid readily changes into ammonical form of nitrogen. Therefore, it is of great value in soil fertility maintenance, if it is added to soil in areas of its abundance.

\section{Materials and Methods}

\section{Experimental details}

\section{Seed source}

For the present study, seeds of wheat variety PBW-550 were obtained from Department of agriculture Dehradun, Uttarkhand.

\section{Description of variety}

The wheat variety PBW 550 is a yellow rust resistant version of PBW 550. Its average plant height is $86 \mathrm{~cm}$ and matures in about 145 days. Its average grain yield is 23.0 quintals per acre. It is resistant to yellow and brown rusts and susceptible to loose smut.

\section{Design and layout}

The experiment will be laid out in a Randomized block design (RBD) with three replications. The experimental details and lay out plan are given below:

Crop: Wheat (Triticum aestivum L.).

Variety: PBW-550

Spacing: $22.5 \mathrm{~cm} \times 10 \mathrm{~cm}$

Design: Randomized block design (RBD)

Replications: 03

Total treatments: 09

Gross plot: $2.5 \mathrm{~m} \times 1.5 \mathrm{~m}$

Irrigation channel: $0.5 \mathrm{~m}$

\section{Treatment details}

$\mathrm{T}_{1}-\mathrm{RDF}$

$\mathrm{T}_{2}$ - EC (1/4) basal + PM (3/4) basal

$\mathrm{T}_{3}$ - FYM (1/4) basal + VC (3/4) basal

$\mathrm{T}_{4}$ - FYM (1/4) basal + PM (3/4) basal

$\mathrm{T}_{5}-\mathrm{EC}(1 / 4)$ basal + VC (3/4) basal

$\mathrm{T}_{6}-\mathrm{FYM}$ (1/4) basal + PM (3/4) top dressing 30DAS

$\mathrm{T}_{7}$ - EC (1/4) basal + VC (3/4) top dressing @ 30 DAS 
$\mathrm{T}_{8}$-EC (1/4) basal + PM (3/4) top dressing at 30DAS

$\mathrm{T}_{9}$ - Control

Note 1: All organics are made equivalent to recommended dose of nitrogen (RDN)

Note 2: FYM: Farm yard manure, VC: Vermicompost, PM: Poultry manure, EC: Enriched compost

Note 3: RDF (recommended dose of fertilizers 100:75:50 kg NPK ha-1)

\section{Sowing of seed}

The seeds of wheat were sown in the field on $16^{\text {th }}$ November 2018. The seeds were sown directly into the plots made on main field. Sowing was done in row spaced $22.5 \mathrm{~cm}$ later seeds were covered manually. Soon after sowing the plots were irrigated and then regular irrigations were applied at an interval of 10 days.

\section{Harvesting and threshing}

Crop was harvested on $10^{\text {th }}$ April 2018 after attaining physiological maturity. The harvested crop was dried in the sun and weighed before threshing. Each plot was threshed separately as per treatment and the weight of grains per plot was recorded in $\mathrm{kg}$.

\section{Yield components}

Ear length, grain weight and number of grain per ear

The ears were randomly selected from the samples collected from each plot. These were measured from the base on the tip of the ear and were expressed in centimetres. These area were threshed to record grain weight ear $^{-1}$ in $\mathrm{g}$, based on 1000 grain weight, grain number per ear was calculated.

\section{Grain weight per $m$ row length}

The plat samples which were collected for total dry matter production at harvest from net plot, the ears from them were threshed and weighed.

\section{Grain and straw yield per net plot}

The total Biomass yield for each net plot was recorded. After threshing, grains were cleaned, separated and weighed. Straw yield was worked out by subtracting respective total grain weight from the total biomass. Later the yield was converted into $\mathrm{kg} \mathrm{ha}^{-1}$.

\section{Harvest index (HI)}

From the yield of grain and straw, the harvest index recording was calculated by using the formula given by Donald (1692) as follows.

$\mathrm{HI}=$ Grain yield $\left(\mathrm{kg} \mathrm{ha}^{-1}\right) /$ Grain yield + straw yield $\left(\mathrm{kg} \mathrm{ha}^{-1}\right)$ or Economical yield/biological yield.

\section{Test weight}

A grain sample collected from net plot was used for recording the 1000 grain weight and was expressed in (g).

\section{Results and Discussion}

The results of experiment conducted to study the effect of organic manures on growth, yield and grain quality of wheat (Triticum aestivum L.) during Rabi season 2018-2019 are presented in this paper (Fig. 1).

\section{Yield parameters}

\section{Ear length (cm) at harvest}

Data on ear length was significantly differed among treatments and presented in Table 1 and depicted through Fig. 2. 
Ear length was significantly greater in $\mathrm{T}_{8}-\mathrm{EC}$ (1/4) basal + PM (3/4) top dressing @ 30 DAS $(9.00 \mathrm{~cm})$. It was followed by $\mathrm{T}_{6}-\mathrm{FYM}$ (1/4) basal + PM (3/4) top dressing @ 30 DAS $(8.59 \mathrm{~cm})$ which were found to be on par with $\mathrm{T}_{2}$ - EC (1/4) basal + PM (3/4) basal $(8.27 \mathrm{~cm})$ Significantly the lowest ear length $(6.98 \mathrm{~cm})$ was recorded in $\mathrm{T}_{9^{-}}$Control.

\section{Number of grains per ear}

Data pertaining to number of grains per ear as influenced by different treatments are presented in Table 1 and depicted in Fig. 2. It was $\mathrm{T}_{8^{-}} \mathrm{EC}$ (1/4) basal + PM (3/4) top dressing @ 30 DAS, which recorded significantly the highest grain number(40.78) and it was on par with $\mathrm{T}_{6}$ - FYM (1/4) basal + PM (3/4) top dressing @ 30 DAS (381.32) and $\mathrm{T}_{2}$ - EC (1/4) basal + PM (3/4) basal (36.50).The lowest number of grains per ear
(34.21) was recorded in $\mathrm{T}_{9}$ - Control.

\section{Grain weight (g) per ear}

Data pertaining grain weight (g) as influenced by different treatments are presented in Table 1 and depicted in Fig. 2.

$\mathrm{T}_{8}$ - EC (1/4) basal + PM (3/4) top dressing @ 30 DAS recorded the highest grain weight $(1.46 \mathrm{~g})$ and it was on par with $\mathrm{T}_{6^{-}}$ FYM (1/4) basal + PM (3/4) top dressing @ 30 DAS (1.43 g) and $\mathrm{T}_{2}$ - EC (1/4) basal + PM (3/4) basal (1.35 g). The lowest (1.03 g) was recorded in $\mathrm{T}_{9}$ - Control.

\section{Grain yield (q ha $\left.{ }^{-1}\right)$}

Data pertaining to grain yield $\left(\mathrm{q} / \mathrm{ha}^{-1}\right)$ as influenced by different treatments are presented in Table 2 and depicted in Fig. 3.

Table.1 Ear length, No. of grains and Grain weight as influenced by organic manures

\begin{tabular}{|c|c|c|c|}
\hline Treatments & $\begin{array}{c}\text { Ear } \\
\text { length } \\
(\mathrm{cm})\end{array}$ & $\begin{array}{c}\text { No.of } \\
\text { grain/ear }\end{array}$ & $\begin{array}{c}\text { Grain } \\
\text { weight/ear } \\
\text { (g) }\end{array}$ \\
\hline $\mathbf{T}_{1-} \mathbf{R D F}$ & 8.22 & 36.26 & 1.24 \\
\hline $\mathrm{T}_{2-}$ EC (1/4) basal + PM (3/4) basal & 8.27 & 36.50 & 1.35 \\
\hline 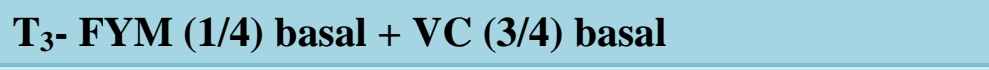 & 7.32 & 35.28 & 1.08 \\
\hline T $_{\text {- }}$ FYM (1/4) basal + PM (3/4) basal & 7.91 & 36.10 & 1.22 \\
\hline $\mathrm{T}_{5}-\mathrm{EC}(1 / 4)$ basal + VC (3/4) basal & 7.55 & 35.62 & 1.12 \\
\hline T6- FYM (1/4) basal + PM (3/4)top dressing @ 30 DAS & 8.59 & 38.32 & 1.43 \\
\hline $\mathrm{T}_{7^{-}}$EC (1/4) basal + VC (3/4) top dressing @ 30 DAS & 7.81 & 35.75 & 1.18 \\
\hline T8- EC (1/4) basal + PM (3/4) top dressing @ 30 DAS & 9.00 & 40.78 & 1.46 \\
\hline $\mathbf{T}_{9}-$ Control & 6.98 & 34.21 & 1.03 \\
\hline $\mathbf{C D}(\mathbf{p}=\mathbf{0 . 0 5})$ & 0.133 & 0.457 & 0.046 \\
\hline C.V. & 0.950 & 0.717 & 2.131 \\
\hline S.Em \pm & 0.044 & 0.151 & 0.015 \\
\hline
\end{tabular}


Table.2 Grain yield, straw yield, harvest index and test weight (g)

\begin{tabular}{|c|c|c|c|c|}
\hline \multirow[b]{2}{*}{ Treatments } & \multicolumn{2}{|c|}{ Yield(q/ha) } & \multirow{2}{*}{$\begin{array}{l}\text { Harves } \\
t \text { index }\end{array}$} & \multirow{2}{*}{$\begin{array}{l}\text { Test } \\
\text { weight } \\
\text { (g) }\end{array}$} \\
\hline & Grain & Straw & & \\
\hline$T_{1}-$ RDF & 25.73 & 40.17 & 36.74 & 32.11 \\
\hline$T_{2}-\operatorname{EC~(1/4)~basal~+~PM~(3/4)~basal~}$ & 26.16 & 44.28 & 36.79 & 33.23 \\
\hline T $_{3^{-}}$FYM (1/4) basal + VC (3/4) basal & 22.17 & 34.80 & 36.05 & 28.32 \\
\hline T $_{4^{-}}$FYM (1/4) basal + PM (3/4) basal & 25.11 & 38.53 & 36.52 & 31.30 \\
\hline$T_{5-}$ EC (1/4) basal + VC (3/4) basal & 23.61 & 37.55 & 36.15 & 29.82 \\
\hline T 6 - FYM (1/4) basal + PM (3/4)top dressing @ 30 DAS & 27.38 & 44.54 & 37.81 & 33.93 \\
\hline $\mathrm{T}_{7}-\mathrm{EC}(1 / 4)$ basal + VC (3/4) top dressing @ 30 DAS & 23.73 & 37.20 & 36.90 & 30.11 \\
\hline$T_{8}$ EC (1/4) basal + PM (3/4) top dressing @ 30 DAS & 28.53 & 46.26 & 38.82 & 35.26 \\
\hline $\mathbf{T}_{9}-$ Control & 20.21 & 32.95 & 34.23 & 26.81 \\
\hline $\mathrm{CD}(\mathrm{p}=\mathbf{0 . 0 5})$ & 0.129 & 0.669 & 0.790 & 0.595 \\
\hline C.V. & 0.298 & 00.968 & 1.237 & 1.097 \\
\hline S.Em \pm & 0.043 & 0.221 & 0.261 & 0.197 \\
\hline
\end{tabular}

Fig.1 Plan layout of the experimental site

$$
\text { R-I }
$$
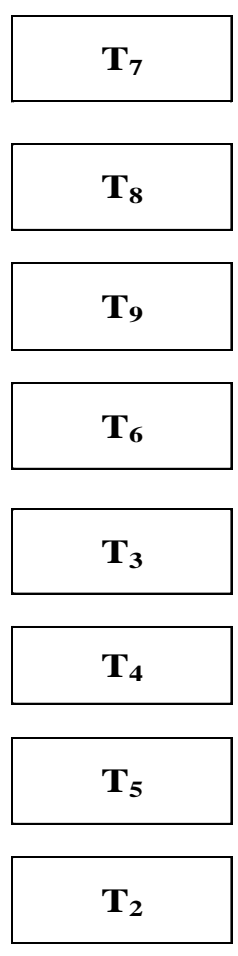

$\mathbf{T}_{1}$
R-II
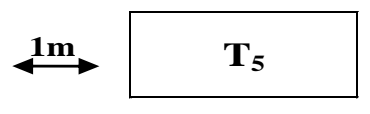

$\mathbf{T}_{2}$

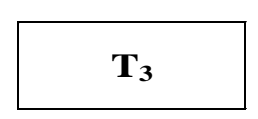

$\mathbf{T}_{4}$

$\mathbf{T}_{1}$

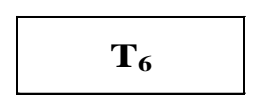

$\mathbf{T}_{7}$

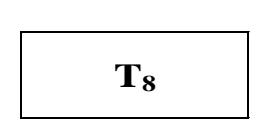

$\mathbf{T}_{9}$
R-III

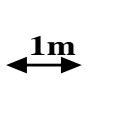

$\mathbf{T}_{9}$

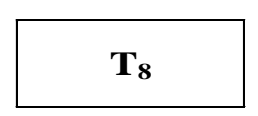

$\mathbf{T}_{7}$

$\mathbf{T}_{4}$

$\mathbf{T}_{5}$

$\mathbf{T}_{2}$

$\mathbf{T}_{\mathbf{1}}$

$\mathbf{T}_{3}$ 
Fig.2 Ear length, no. of grains and grain weight as influenced by organic manures

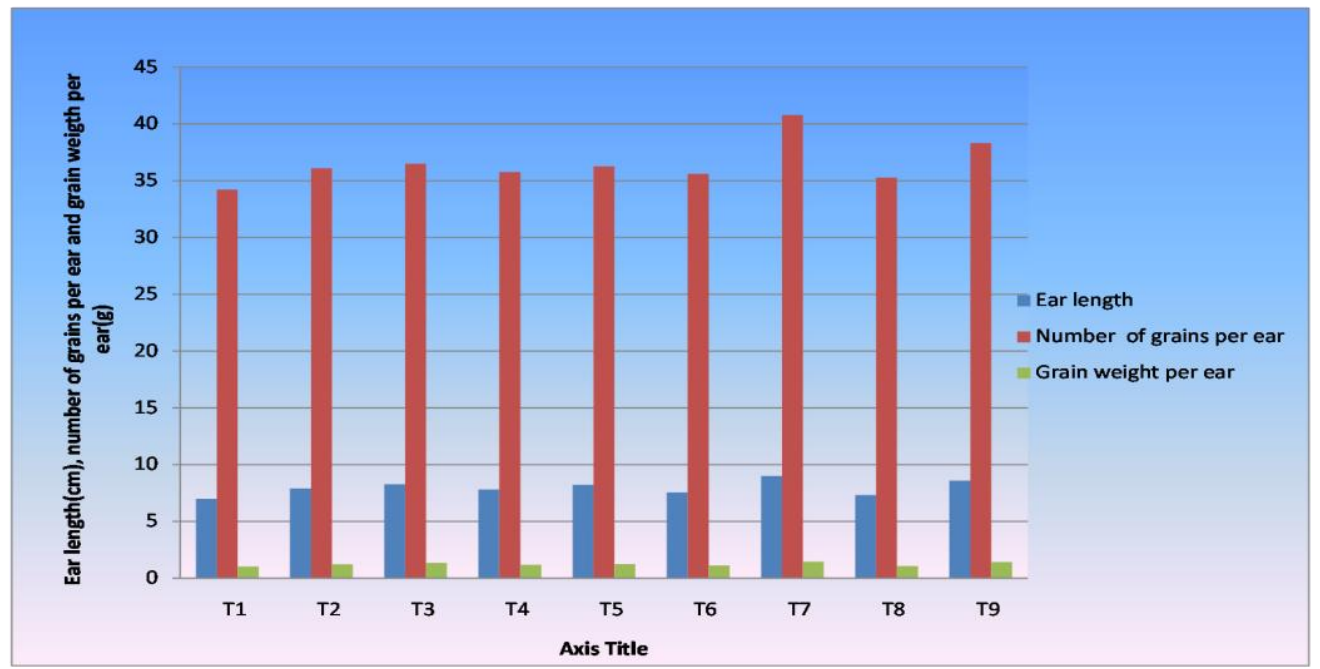

Fig.3 Grain yield, straw yield, harvest index and Test weight (g) as influenced by organic manures

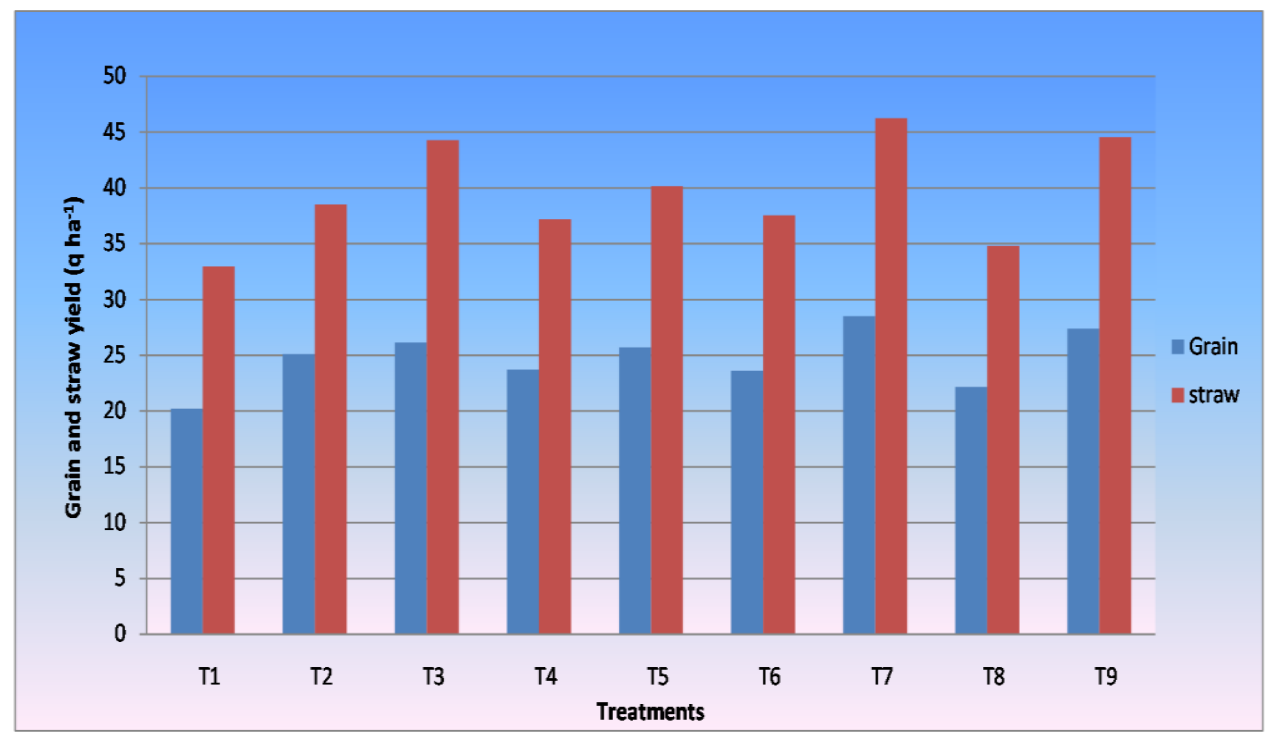

Significantly higher grain yield $(28.53 \mathrm{q})$ was recorded in $\mathrm{T}_{8}$ - EC (1/4) basal + PM (3/4) top dressing @ 30 DAS which was closely followed by $\mathrm{T}_{6}$ - FYM (1/4) basal + PM (3/4) top dressing @ 30 DAS (27.38 q) and $\mathrm{T}_{2}$ - EC (1/4) basal + PM (3/4) basal (26.16 q). The lowest grain yield $(20.21 \mathrm{q})$ was recorded in $\mathrm{T}_{9^{-}}$Control.

\section{Straw yield (q ha $\left.{ }^{-1}\right)$}

Data pertaining to straw yield $\left(\mathrm{q} / \mathrm{ha}^{-1}\right)$ as influenced by different treatments are presented in Table 2 and depicted in Fig. 3.

$\mathrm{T}_{8}$ - EC (1/4) basal + PM (3/4) top dressing @ 30 DAS recorded significantly higher $(46.26$ q) straw yield followed by $_{6}-$ FYM (1/4) 
basal + PM (3/4) top dressing @ 30 DAS $(44.54 \mathrm{q})$ which was on par with $\mathrm{T}_{2}$ - EC (1/4) basal + PM (3/4) basal (44.28 q). The lowest straw yield $(32.95 \mathrm{q})$ was recorded in $\mathrm{T}_{9}$ Control

\section{Harvest index (\%)}

The data on harvest showed that the treatments did not differ significantly between eachother.The significant difference was presented in Table 2 and depicted in Fig. 3.

\section{Test weight (g)}

Data pertaining to Test weight as influenced by different treatments are presented in Table 2 and depicted in Fig. 3.

$\mathrm{T}_{8}$ - EC (1/4) basal + PM (3/4) top dressing @ 30 DAS recorded significantly the highest grain weight $(35.26 \mathrm{~g})$ and it was on par withT $_{6-}$ FYM (1/4) basal + PM (3/4) top dressing @ 30 DAS (33.93 g).T $2^{-}$EC (1/4) basal + PM (3/4) basal (33.23 g). The lowest $(26.81 \mathrm{~g})$ was recorded in $\mathrm{T}_{9}$ - Control.

In conclusion the field experiment was conducted during Rabi 2018-2019 at Agriculture experimental farm of ALPINE institute of technology to study the "Organic Manures Influence on Wheat Yield and Quality". The summary and conclusion of the experiments are given below.

Ear length was significantly greater in $\mathrm{T}_{8^{-}} \mathrm{EC}$ (1/4) basal + PM (3/4) top dressing @ 30 DAS $(9.00 \mathrm{~cm})$. Significantly the lowest ear length $(6.98 \mathrm{~cm})$ was recorded in $\mathrm{T}_{9}-$ Control. It was $\mathrm{T}_{8^{-}} \mathrm{EC}$ (1/4) basal + PM (3/4) top dressing @ 30 DAS, which recorded significantly the highest grain number (40.78. The lowest number of grains per ear (34.21) was recorded in $\mathrm{T}_{9-}$ - Control.

$\mathrm{T}_{8}$ - EC (1/4) basal + PM (3/4) top dressing @
30 DAS recorded the highest grain weight $(1.46 \mathrm{~g})$. The lowest (1.03) was recorded in $\mathrm{T}_{1}$ - Control. $\mathrm{T}_{8}-\mathrm{EC}$ (1/4) basal + PM (3/4) top dressing @ 30 DAS recorded significantly the highest 1000 grain weight $(35.26 \mathrm{~g})$. The lowest $\left(26.81 \mathrm{~g}\right.$ ) was recorded in $\mathrm{T}_{9}$ - Control.

Significantly higher grain yield $(28.53 \mathrm{q})$ was recorded in $\mathrm{T}_{8}$ - EC (1/4) basal + PM (3/4) top dressing@30 DAS. The lowest grain yield (20.21q) was recorded in $\mathrm{T}_{9^{-}}$Control. $\mathrm{T}_{8^{-}} \mathrm{EC}$ (1/4) basal + PM (3/4) top dressing @ 30 DAS recorded significantly higher straw yield (46.26 q). The lowest straw yield (32.95 q) was recorded in $\mathrm{T}_{9-}$ Control. Here we concluded that $\mathrm{T}_{8^{-}} \mathrm{EC}$ (1/4) basal + PM (3/4) top dressing @ 30 DAS has shown significantly highest growth and yield parameters of the crop compare to the other treatments.

\section{References}

Billore. S. D., Joshi O. P., Ramesh. A. and Vyas. A. K., (2009). Enhancing wheat production through tillage and integrated nutrient management. Indian J. Agric. Fert. 5 (11): 25-27.

Donald, C.M., (1962). In search of yield. J. Australian Insti. Agric. Sci., 28: 171178.

Ghosh, P. K., Banadyopahyay, K. K., Tripathi, A. K., Hati, K. M., Mandal, K. G. and Misra, A. K., (2003).Effect of integrated management of farm yard manure, phospho compost, poultry manure and inorganic fertilizers for rain fed sorghum (Sorghum bicolor L.) in Vertisol of Central India. Indian. $J$. Agron., 48(1): 48-52.

Kale, R. D. and Bano, K., (1986).Field trials with vermicompost (vermicompost E. 83, UAS) and organic fertilizer production. In: Proc. of the National Seminar on Organic Waste Utilization of Vermicompost. Part: Verms and 
Vermicompost (Eds.) M. C. Dass, B. K., Senapati and P. C. Mishra, Sri Avtarana Rant, Burla, pp. 151-160.

Naik, I. A. and Gupta, A. J., (2010).Effect of plant density and integrated nutrient management on growth, yield, quality and economics of kale (Brassica oleracea var. acephala) in temperate region. Indian J. Agric. Sci., 80(1): 8084.

Patil, S.V., Halikatti, S.I., Hiremath, S.M., Babalad, H.B., Srinivasa, M. N., Hebsur, N.S., and Somanagouda,
G.(2012). Effect of organics on growth and yield of Chickpea (Cicerarietinum) in verticals. Karnataka J. Agric. Sci., 25(3): 326-331.

Sharma, K. C., (2009).Integrated nitrogen management in fodder oats (Avena sativa) in hot arid ecosystem of Rajasthan. Indian J. Agron.,54(4): 459464.

Srivastava, O. P., (1998). Integrated nutrient management for sustained fertility of soil. Indian J. Agril. Chem., 31(1):1-12.

How to cite this article:

Sivanagalakshmi, Ch., Narendra Singh, Gajendra Singh, Ankush Singh and Pragya Rawat. 2020. Influence of Organic Manures on Yield Components of Triticum aestivum L. Int.J.Curr.Microbiol.App.Sci. 9(08): 3006-3013. doi: https://doi.org/10.20546/ijcmas.2020.908.339 